\title{
A Review: Product Pricing of Islamic Banking in Indonesia
}

\author{
Radia Purbayati, Kurnia Fajar Afgani, and Agil Krisna Rivanda
}

\section{ABSTRACT}

\begin{abstract}
Indonesia is a country with the largest Muslim population in the world with a Muslim population reaching $87 \%$ of the total population. This is an opportunity for Islamic Banks to be able to grow and develop as a bank with the concept of a profit-sharing bank. It is appropriate for all operational activities, including pricing stipulations for Islamic banking products, to be free from the element of interest (interest rate free). However, in practice, there are still pricing stipulations in Islamic banking products that benchmark interest rates. This study aims to review the pricing determination of Islamic banking products in Indonesia. The method used in this research proposal is a literature review. The literature review produced several alternative purposed for the Islamic Pricing Benchmarking method as a benchmark that can be used by Islamic banking in determining the pricing of its products.
\end{abstract}

Keywords: Islamic Banking, Price Benchmarking.

\section{INTRODUCTION}

Islamic banking is a financial institution that operates based on sharia principles without relying on the interest system (QS. Luqman: 34, QS. Ali-Imron: 130, QS. AlBaqarah: 275, An-Nisa: 29). The practice of Islamic banking in the world is experiencing exponential growth. Several countries have implemented a dual banking system such as Bahrain, Bangladesh, Egypt, Indonesia, Jordan, and Malaysia. In practice, Islamic banking is experiencing fierce competition with conventional banking, including in terms of pricing [1]-[3]. Sing [4] said that the dual banking system made the market messy and faced difficulties in creating a rate that freed Islamic banks from the base rate of interest rates, and customers tended to behave in arbitrage. Bashir [5]. argued that benchmarking against interest rates cannot completely differentiate between Islamic and conventional financial products. There is a debate related to benchmarking in determining the pricing of products carried out by Islamic banking towards interest rates.

\section{A. Logic That Supports Benchmarking to Interest Rates}

To standardize the mark up or the rate of profit from different goods / services and investment transactions, the LIBOR interest rate is used as a benchmark until other pricing methods have been determined. Some argue that benchmarks against interest rates are not prohibited but are not desirable.

\section{B. Logic Opposing Benchmarking to Interest Rates}

Bank Indonesia [6] and Ghauri [7] say that sharia banking is closely related to the real sector, so sharia banking operations should reflect the real sector so that it is expected
Submitted : April 19, 2021

Published : May 18, 2021

ISSN: 2507-1076

DOI: $10.24018 /$ ejbmr.2021.6.3.856

Radia Purbayati *

Bandung State of Polytechnic, Indonesia.

(e-mail: radia@ ${ }^{@}$ polban.ac.id)

Kurnia Fajar Afgani

Bandung Institute of Technology,

Indonesia.

(e-mail: kurnia.fajar@sbm-itb.ac.id)

Agil Krisna Rivanda

Bandung State of Polytechnic, Indonesia.

(e-mail: akraagil@gmail.com)

*Corresponding Author to contribute to encouraging sustainable economic growth.

Until now, the determination of product pricing by Islamic banking, both using profit sharing and buying and selling patterns, still refers to conventional interest rates. This is the implication of the dual banking system implementation. Several researchers highlighted the establishment of Islamic banking product pricing. Ismail [8] said that pricing for Islamic banking products is determined directly from money market interest rates such as KLIBOR and LIBOR or the prevailing interbank funds rate with profit margins reflecting the intensity of competition. Several researchers have shown that there is a high correlation between the establishment of pricing for Islamic banking products which refers to the interest rate as the benchmark [8]-[14].

The purpose of this study was to evaluate whether Islamic banking operates according to the principle as bank interest free on determining yield / margin products collection and distribution of funds. The purpose of this research is and to review alternative determination of pricing benchmarking Islamic banking products that can be applied in Indonesia.

\section{LITERATURE REVIEW}

\section{A. Sharia Bank Operational}

The legal basis for Islamic banking practice is based on the Al-Qur'an and Hadith. There is a sharia bank operational philosophy, including:

\section{Element of Riba}

Avoiding the use of a predetermined system in advance with certainty the success of a business (QS. Luqman: 34), avoiding the use of the percentage system for charging debt / 
giving rewards for multiplying savings (QS. Ali-Imron: 130), Avoiding the use of the trading system / renting riba goods in exchange for other riba (HR. Muslim Chapter Riba No. 15511567), avoiding the use of a system that stipulates in advance additional debt that is not an initiative that has debt voluntarily (HR. Muslim Chapter Riba No. 1569-1572).

\section{A system of profit sharing and trading implementation}

Every sharia institutional transaction must be based on a profit-sharing system and trade / transactions that are based on the exchange of goods for money (QS. Al-Baqarah: 275, An-Nisa: 29).

TABLE I: RESEARCH REVIEW

\begin{tabular}{|c|c|c|c|}
\hline Researcher & Year & Research & Result \\
\hline Omar et al. & 2010 & $\begin{array}{l}\text { Developing a benchmark pricing model in the } \\
\text { Islamic financial industry in Malaysia by } \\
\text { conducting a review of benchmark pricing, } \\
\text { examining benchmark pricing at conventional } \\
\text { banks, discussing the theoretical benchmarks of } \\
\text { sharia, testing the feasibility of benchmarks using } \\
\text { simulations. }\end{array}$ & $\begin{array}{l}\text { Rate of Profit Mechanism Model, Rate of Dividen of } \\
\text { Islamic Bank Deposits and Investment Accounts Model, } \\
\text { The creation of an Inter-Islamic_Banks Market Based on } \\
\text { Islamic Principles, Tobin'S q Theory, Modern Finance } \\
\text { Theory on Cost of Fund / Capital. }\end{array}$ \\
\hline $\begin{array}{l}\text { Ismail, Abdul } \\
\text { Ghafar }\end{array}$ & 2010 & $\begin{array}{l}\text { The current application of the pricing method in } \\
\text { Islamic banking and provides several examples of } \\
\text { pricing mechanisms for Islamic banking. }\end{array}$ & $\begin{array}{l}\text { Several Islamic banking pricing methods include cost-plus } \\
\text { pricing, price leadership pricing, credit-scoring systems and } \\
\text { risk-based pricing, as well as profitability analysis. }\end{array}$ \\
\hline $\begin{array}{l}\text { Saba dan Al- } \\
\text { Sayyed }\end{array}$ & 2010 & $\begin{array}{l}\text { Analyzing the use of KIBOR as a benchmark for } \\
\text { determining the pricing of Islamic banking products } \\
\text { in Pakistan. }\end{array}$ & $\begin{array}{l}\text { The Hedonic Model can be used to determine product } \\
\text { pricing as an alternative method in Islamic banking pricing. }\end{array}$ \\
\hline $\begin{array}{l}\text { Researchers of } \\
\quad \text { Islamic } \\
\text { Depertement BI }\end{array}$ & 2013 & $\begin{array}{l}\text { The determination of pricing for Islamic banking } \\
\text { products in Indonesia uses a literature study by } \\
\text { reviewing the most relevant literature to create a } \\
\text { pricing indicator based on the real sector as the } \\
\text { operational of Islamic banks. }\end{array}$ & $\begin{array}{l}\text { Real sector indicators can reflect the real rate of return of } \\
\text { each industrial sector and can be used by Bank Indonesia to } \\
\text { monitor real sector performance and analyze gaps arising } \\
\text { from the real sector and the financial sector. Based on the } \\
\text { benchmark real rate of return, an Islamic banking return } \\
\text { index can be formulated that reflects the yield performance } \\
\text { of the Islamic banking industry. }\end{array}$ \\
\hline Habbani, Elhadi & 2013 & $\begin{array}{l}\text { Seeing whether Islamic banking is free from usury } \\
\text { or uses the same benchmarks and calculation } \\
\text { methods that are applied to conventional banks. }\end{array}$ & $\begin{array}{l}\text { Islamic banking focuses more on contracts that are not } \\
\text { prohibited rather than emphasizing the purpose of } \\
\text { prohibiting usury in determining the rate of profit. }\end{array}$ \\
\hline $\begin{array}{l}\text { Supriyanto, } \\
\text { Trisiladi }\end{array}$ & 2016 & $\begin{array}{l}\text { To find the concept of profit levels in Islamic } \\
\text { banking that can create economic justice and } \\
\text { stability in the Islamic Financial Market and } \\
\text { determine the role of profit levels in creating } \\
\text { financial stability, especially in ALMA } \\
\text { management. }\end{array}$ & $\begin{array}{l}\text { The level of profit in Islamic banking that produces income } \\
\text { distribution is measured by Net Margin stability. The level } \\
\text { of profit that creates an even distribution of wealth in the } \\
\text { Islamic capital market can be seen from the volatility of } \\
\text { Islamic financial assets such as sukuk. A risk premium is } \\
\text { added to the price structure of Islamic financial assets. }\end{array}$ \\
\hline
\end{tabular}

Source: various journals, reprocessed.

\section{Methodology}

Type of research method used in this research proposal is literature review. Qualitative research methods allow researchers to explore and better understand the complexity of a phenomenon [27]. Literature review is the use of ideas in literature to justify specific approaches related to topics, selection, methods, and demonstrations that this research contributes to something new [28]. Meanwhile, Webster and Watson [29] define an effective literature review as one that creates a solid foundation for advancing knowledge. J. Shaw [30], and Levy \& Ellis [31] note that the review process should explain how one study can build on another. A literature review can be useful when [32]:

1) Researchers want to evaluate theory and evidence in a particular area or test the validity or accuracy of a particular theory;

2) Aims to develop an overview of an issue or research problem. Literature reviews are conducted to evaluate statements of knowledge on a particular topic;

3) Useful for creating a research agenda, identifying research gaps and discussing something that happened;

4) Provide a basis for building a new conceptual model or theory and can be meaningful when mapping research developments.

\section{A. Literature Review Process}

The literature review approach in this study uses an inputprocessing-output approach. Levy and Ellis [31] define the literature review process as sequential steps to collect, know, understand, apply, analyze, synthesize and evaluate quality literature to provide a solid basis for a topic and research method. The literature review process that will be carried out in this study consists of three stages:

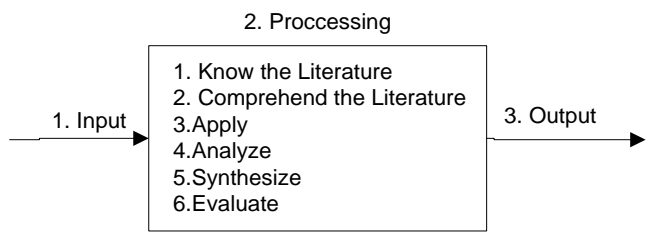

Fig. 1. Literature Review Method. Source: [33].

\section{B. Input}

This section discusses the main issues associated with the process of understanding literature quality as well as the process of collecting manuscripts for an effective literature review. The input stage is carried out by collecting various journals related to this topic and testing their application to the study. This process is carried out by validating the quality of the literature information system sourced from various 
literature vendors such as ProQuest, Elsevier, Informs, IEEE, Wilson, Thomson, ACM, EbscoHost, and listing journals as a source of information systems. The next step is to identify and test applicability to the study.

\section{Processing}

The data that has been collected and identified is processed into an information system that provides the basis for new research that can be built. Steps taken starting from:

1) know the literature is the activity of listing, defining, describing, and identifying, demonstrating articles that have been read and extracting information from the articles read;

2) comprehend the literature is an understanding done by summarizing, differentiating and interpreting activities;

3) cognitive / construct aims to discuss specific theoretical constructs;

4) apply the literature is an application shown by activities demonstrating, describing, completing, connecting, and clarifying. Application is carried out by identifying the main concepts closely with the study and placing the citations in the correct categories;

5) analyzed the literature are activities carried out by separating, connecting, comparing, selecting and explaining;

6) synthesize the literature is this activity of combining, integrating, modifying, organizing, designing, compiling and generalizing the essence of the synthesis to collect literature reviewed for a given concept into a whole that exceeds the sum of its parts;

7) evaluate the literature is an activity carried out by assessing, deciding, recommending, selecting, explaining, discriminating, supporting and concluding.

\section{Output}

At this stage, the argumentation development review literature is produced clearly and has a logical structure. The input-processing-output approach is carried out with a metanarrative method, namely a systematic way of making complex, heterogeneous and contradictory definitions of the literature [34]. The following picture is the steps in the metanarrative method.

\section{RESEARCH RESULT}

\section{A. Determination of Pricing Application of Islamic Banking in Indonesia}

In several countries, including Indonesia, the application of the banking system is running using a dual banking system, namely the conventional banking system with the principle of interest rate, and the Islamic banking system with the principle of Profit and Loss Sharing (PLS). In line with the growth and development of Islamic banking as an alternative to a bank that offers the concept of interest rate free in an economy that operates with a dual banking system, the two banking systems are experiencing intense competition, including determining pricing for fund collection and distribution products [8]-[14].

The tight banking competition between Islamic banking and conventional banking has resulted in a mutually influencing relationship in determining the pricing. Policy changes in the interest rate for savings and credit products at conventional banks will affect the policy for changes in the yield / profit margin of savings and financing products in Islamic banking, and vice versa. Meanwhile, on the one hand, Islamic banking must still run based on Sharia, where banks operate with the concept of interest rate free. Radia [14] conducted an evaluation of the practice of Islamic banking in Indonesia and found that the pricing determination of fund collection and distribution products in Islamic banking is determined by each time lag of the variable collection and distribution of funds (credit) in Islamic banking and conventional banking, as well as otherwise. Adjustments occur for the short-term to long-term shocks of each variable in response to these shocks. The existence of a relationship between the interest rate in determining the pricing of fundraising products and the distribution of Islamic banking funds indicates that the practice of Islamic banking in Indonesia has not been completely free from the element of interest rates. This is because the market captured by Islamic banking is not only aimed at customers with the sharia loyalist market segment, but also customers with the floating market segment who tend to choose the lowest cost or the highest return between conventional banks and Islamic banks.

\section{B. Review of Proposed Benchmarking Pricing Methods}

Several researchers have proposed several approaches to pricing products for raising and distributing funds to banks, including :

1. Sharia Capital Market Interbank Benchmark (Thomson Reuters, 2011)

The proposed approach is the Islamic Capital Market Interbank benchmark level approach managed by Thomson Reuters.

TABLE II: THOMSON REUTERS PROXY AND PRICING STAGES

$$
\text { Proxy used in benchmarking }
$$

1. Pricing for short-term treasury overnight investments and financing instruments such as Murabahah, Wakalah and Mudharabah.

2. Pricing of retail financing instruments such as property financing, car financing and other asset financing.

3. Pricing/benchmarking company finance and investment assets.

4. Pricing of Sukuk and other fixed income instruments in accordance with Sharia. The official merger may be for price fixing to confirmations / attachments related to the Master Sharia-compliant Hedging Agreement.
The Pricing Determination Stages

1. Tariffs for Sharia compliant US Dollar (USD) funding in reasonable market sizes are contributed through the Thomson Reuters system every business day between 9.00 and 10.44 (Makkah time - GMT +3 ) by a panel of at least 18 Sharia banks.

2. Panels contribute their rates based on predetermined questions as determined by the Sharia Benchmarking Committee and approved by the Sharia Committee.

3. Fares are set by Thomson Reuters at 10.45 am. Thomson Reuters performs automated and manual audits and review procedures at this stage to ensure that rates contributed are

4. Tariffs are ranked from highest to lowest and upper and lower quartiles $(25 \%)$ of the rates are excluded to ensure that outliers do not affect distribution (Out of 18 contribution levels, 8 rates are excluded - 4 rates are highest and lowest rates respectively).

5 . The arithmetic mean (mean) of the remaining middle quartile values is then calculated to produce the IIBR, rounded up to 5 decimals. 


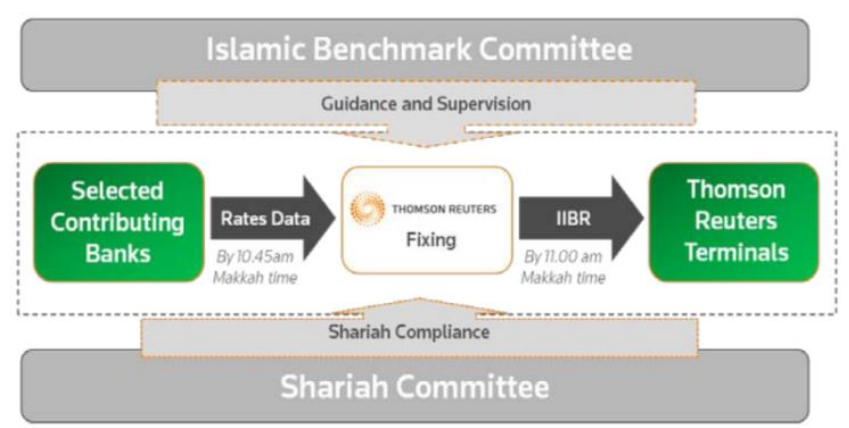

Fig. 2. Thomson Reuters Pricing Stages. Source: financial.thomsonreuters.com/islamicbenchmark.

\section{Islamic Pricing Benchmarking Model (IPBM)}

The Index Price Benchmarking Model (IPBM) approach relies on estimating the rate of return for each project taking into account the expected future cash flows relative to the invested capital [13]. Future cash flows take into account general economic conditions such as growth or certain other factors. Therefore, investors should be given a feasibility study for a new project to determine expected cash flows and other important indications. Thus, Islamic financial institutions (investors) provide financial needs by taking into account the IPBM results that reflect the data obtained from the feasibility study. So modeling focuses on the difference between cash inflows and outflows, which are basically evaluated by studies dealing with investment decisions. Net Present Value and Internal Rate of Return were determined using this method. NPV aims to determine the net value of current assets by relying on a previously assumed discount rate. Thus, NPV is a tool used to calculate cash flows based on a predetermined future value, relative to the current cash flows of assets. IRR is used as another general indicator to determine whether an investment decision is profitable or not.

\section{Index Of Real Sector Returns}

Central Bank of Indonesia [25] proposes the development of a micro model of a commodity market equilibrium analysis. There are several basic principles of this model, namely:

1) monetary policy that focuses on the role of financing in the financial system;

2) the market is never perfect. With the imperfect market and the high cost of obtaining information, the role of banks has become more important and central in the financial system;

3) the ability and willingness of banks to channel financing is influenced by many factors, namely internal factors (bank capital, offered interest rates, etc.) and external factors (banking competition, monetary policy, etc.).

The rate of return can be projected from the average normal returns obtained by companies in various real sectors [24]. From the micro (company) side, the normal average return can be seen from several indicators such as RoA (Return on Assets), RoI (Return on Investment), and RoE (Return on Equity). If the incentive system functions properly and all actors work optimally, the real sector growth and economic growth will increase so that the efficiency of the financial system can also increase. This model assumes that profitability is determined by the market structure where the determinant variable works in equilibrium conditions.

\section{Real Sector Profitability Modeling}

\section{Profitability Model in Cost Structure}

This model uses a structured-market conduct model (SCP) approach where profitability is an indicator of market performance. The SCP model assumes that profitability is determined by the market structure where the determinant variable works in equilibrium conditions. The movement of variable values in certain industrial subsectors can affect other subsectors without explaining the transmission of influence between variables. One of the factors in a structured market is the cost structure proposed by Scherer [35] \& Ross [36]. In this modeling, the output of the upstream industry becomes the input for other industrial sub-sectors (downstream industry). Another factor that is usually taken into account in calculating real sector returns, especially those that do not go through interest rates, is the cost structure and industrial returns.

\section{Profitability Model using CRR}

Another method developed is the Cash Recovery Rate (CRR) introduced by Ijiri in Gordon and Hamer [37]. The cash recovery rate of return (CRR) is used as a measure of profitability. The industrial IRR can be calculated from the implications of the empirical CRR value. This shows that the CRR can be used as a basis for calculating the IRR or profitability of a particular sector. However, this procedure is still limited to public companies and the resulting IRR value may differ from the cost of capital. In general, the real sector return index as a reference for Islamic banking product prices is expected to be:

1) to determine how to analyze non-interest returns. Calculation of the nominal value of each variable into the real value measurement to capture the impact of fluctuations in price changes in general;

2) calculating the non-interest returns of the selected sectors that are the focus of the analysis using the Cash Recovery Rates (CRR);

3) The establishment of an industry index per sector in the second stage, by carrying out a certain weighting of the company;

4) Analyzing the relationship between macro factors and CRR by sector and forecasting.

\section{House Pricing Index}

Salina Hj Kassim, Nur Harena Redzuan, \& Nor Zalina Harun [38] propose a method of calculating home ownership financing in Islamic banks using the House Pricing Index as an alternative interest rate as a benchmark for Islamic home financing products. A series of empirical tests to determine the relationship between HPI and macroeconomic indicators and housing was carried out using multivariate time series analysis based on Auto-Regressive Distributed Lag (ARDL). The ARDL model used in this study can be written as the following general model :

$$
\text { HPIt }=\alpha 0+\beta 1 \mathrm{Vt}+\beta 2 \mathrm{Wt}+\beta 3 \mathrm{Xt}+\beta 4 \mathrm{Yt}+\beta 5 \mathrm{Zt}+\epsilon \mathrm{t}
$$

where:

HPI : House Price Index;

$\mathrm{V}$ : Housing loan;

W: Production of other goods from concrete, cement and plaster;

X: Production of basic iron and steel products; 
Y: Production of products related to construction;

Z: Real Gross Domestic Product.

In establishing the existence of a long-term relationship between house prices and its determinants, this study uses the ARDL-based boundary testing procedure suggested by Pesaran, Shin and Smith [23]. The ARDL model is expressed in the form of infinite error correction stated below:

$$
\begin{gathered}
\Delta \mathrm{HPIt}=\theta 0+\theta 1 \mathrm{HPI} \mathrm{t}-1+\theta 2 \mathrm{Vt}-1+\theta 3 \mathrm{Wt}-1+\theta 4 \mathrm{Xt}-1+ \\
\theta 5 \mathrm{Yt}-1+\theta 6 \mathrm{Z} \mathrm{t}-1+\Sigma \emptyset k i=11 \mathrm{t}
\end{gathered}
$$

HPI t-1 (2) $+\Sigma \emptyset k i=02 \mathrm{t} \mathrm{Vt}-1+\Sigma \emptyset k i=03 \mathrm{t} \mathrm{Wt}-1+\Sigma \emptyset$ $k i=04 \mathrm{t} \mathrm{Xt}-1+\Sigma \emptyset k i=15 \mathrm{t} \mathrm{Yt}-1+\Sigma \emptyset k i=15 \mathrm{t} \mathrm{Z} \mathrm{t}-1+\mu \mathrm{t}$

where $\Delta$ is the first difference operator, $\mathrm{k}$ is the optimal lag length. The use of non-interest benchmarks will result in a more stable price movement based on the real value of the property. For financing activities, the benchmarks can vary according to the real sector and product of concern. The benchmark derived from the real sector of the economy prevents disputes and arguments between parties involved in pricing of financial products. Also presenting honesty in the banking business with transparency in benchmarks used in determining prices. Thus, this increases the level of public trust and confidence in the Islamic financial system.

5. Capital Asset Pricing Model (CAPM) Dan Arbitrage Asset Pricing (ABT)

Prof. Dato 'Dr. Mohd Azmi Omar, Asst. Prof. Dr. Azman Md Noor, and Prof. Dr. Ahamed Kameel Mydin Meera [39] proposes the Capital Asset Pricing Model (CAPM), which relates the market risk of a project or business with the required rate of return. The required return is the cost of equity, and if the IRR falls above the required level then the project is viable and provides a positive NPV for the investor.

This study aims to find a feasible sharia benchmark price as a substitute for the market interest rate currently used as a benchmark in Islamic finance. Sharia pricing must be based on the risk profile of real economic businesses that encourage profit seeking but hate interest taking (usury). Profits are linked to real economic activity and are subject to risk taking. Therefore, benchmarks must be based on the level of profit that comes from the real sector based on the productivity and profitability of assets. The estimated expected return based on the risk profile will serve as a baseline for the cost of capital for each sector, while the unique risk for the company or business is an additional cost.

The Arbitrage Asset Pricing Theory (APT) is recognized as a better model than the CAPM model. This model proposes that four macroeconomic variables have good predictability of returns for all sectors: industrial production growth, to capture overall economic growth; the money supply changes (M2), to capture monetary liquidity; the ringgit exchange rate, to reflect relative competitiveness globally; and the Kuala Lumpur Composite Index, to reflect overall market conditions. The weighted average of the sectoral returns determined via the APT is suggested here as a viable Islamic benchmark price for the market as a whole. In order to obtain the pricing rate, the calculation is based on a weighted average based on market capitalization of sectoral benchmarks. The proposed benchmark is not only compatible with sharia, which is based on profitability and risk profile, it is also found to be more stable than the interest rate. The benchmark interest rate simulations for the financial industry were also found to be comparable to actual price levels based on EBIT, suggesting that the proposed asset-based cost of interest-free funds could be used in place of conventional interest-based cost of funds.

Such a proposed price benchmark model could be used by other central banks and Islamic financial institutions around the world. However, the individual factor loads will need to be estimated and combined into the model to obtain the respective market benchmarks. Furthermore, the likelihood of default, i.e. incorporating company-specific risk, can be estimated and added to the benchmark level. With such sharia price benchmarks, it is hoped that current Islamic finance can be freed from the use of conventional benchmarks such as KLIBOR, COFI or LIBOR. Islamic finance can then be independent from conventional finance and truly become an alternative to it and be able to handle and reduce the flow of global economic and financial crises.

\section{Islämic Finance Benchmark}

Mirakhor 1996[40] presented a model by utilizing the Q ratio as a major component to arrive at the Cost of Capital. The theoretical model describes the possibility of obtaining a Cost of Capital without using any interest rate benchmarks. Mohsin Ali and Choudhary Wajahat Naeem Azmi [24] propose a model based on the existing assumption that there is no interest-based benchmark and therefore the only source of financing available in financial markets is equity. Mirakhor uses the Q model to create the following model :

$$
p=\frac{Y}{V}(1-d+d q)
$$

Where :

$\mathrm{P}$ : cost of captal of company value or rate of return required by shareholders.

Y: expected revenue value for the next year.

$\mathrm{V}$ : present value of the firm's capital stock.

$D$ : the share of profit that the company hopes to retain and the expected rate of share financing is expressed as the ratio of the company's expected earnings.

$\mathrm{q}$ : the company's $\mathrm{Q}$ ratio.

Mirakhor [40] also emphasized that the concept of the Q ratio can be used by the government to finance the project. Iqbal [41] also supports Mirakhor's model and argues that it can solve major gaps in the Islamic financial system. Moreover, he is of the opinion that the available alternatives are limited to the macro level only. The benchmark based on the $\mathrm{Q}$ ratio can also serve the purpose at the micro level as a company and a bank.

\subsection{Q Ratio Measurement}

The theoretical model of the $\mathrm{Q}$ ratio developed by Tobin [42] is defined as the ratio of the market value of one additional unit of capital (also known as the image price of capital) to substitute costs, known as "Marginal Q". But the image of the capital price is forward looking and hence Marginal Q cannot be observed. Q that can be observed is "Average Q", which is the ratio of the market value of the company's assets to the cost of replacing its assets. Hayashi [43] describes an assumption whereby Marginal Q will be equal to average $\mathrm{Q}$. The assumptions are competitive markets, linear homogeneity of production technology and 
adjustment costs.

This model was proposed by Abbas Mirakhor (1996) by utilizing the Tobin's Q2 concept to arrive at the cost of capital $(\mathrm{CoC})$ without using a fixed interest rate. Empirical testing of the model on Malaysian companies. To arrive at $\mathrm{CoC}$, we lowered the Q-ratio at the company level and gathered the same at the industry level. Our findings suggest that the model proposed by Mirakhor [40] can be used to estimate $\mathrm{CoC}$ in an interest-free economy.

\section{Rate Of Profit As A Pricing Benchmark In Islamic Banking}

Dr. Trisiladi Supriyanto, M. Si [44] uses quantitative research to see the effect of interest rate volatility represented by Bank Indonesia Certificates (along with other factors such as balance sheet structure) on net margin (the profit rate of Islamic banks).

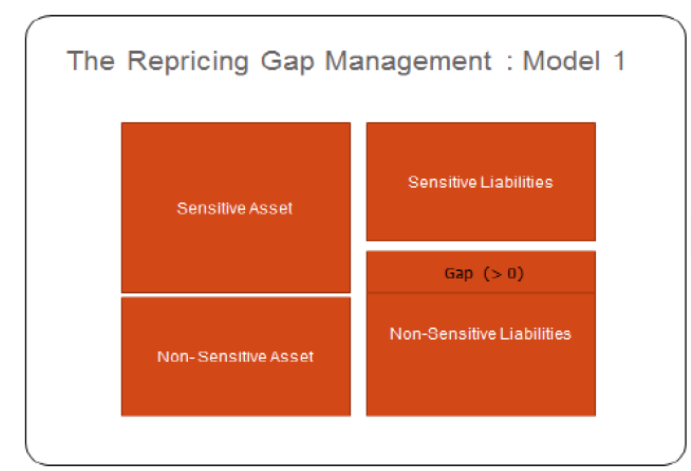

Fig. 3. Repricing GAP Management.

Source: Presented At International Conference On Islamic Economic and Finance October 29, 2016.

Gap adjusted maturity will determine the level of net income of Islamic banks.

\begin{tabular}{|l|l|l}
\hline \multicolumn{3}{c}{ Gapping Period : 12 month } \\
\hline Today $\quad \mathrm{p}=1 / 12$ & 1 year \\
\hline Fixed Rate & New Rate Condition \\
\hline & 11 month
\end{tabular}

$$
i i j=s a j \cdot r j \cdot p j+s a j \cdot(r j+\Delta r j) \cdot(1-p j)
$$

$\mathrm{Pj}=$ asset-liability repricing date in 1 year

Fig. 4. Gap adjusted maturity.

Source: Presented At International Conference On Islamic Economic and Finance October 29, 2016.

The role of the level of profit in creating wealth distribution as measured by the volatility of the asset value of Islamic financial products:

- Asset Value Volatility can be reduced:

$$
\left(\frac{\mathrm{dV}}{\mathrm{V}}\right)=-\mathrm{n}\left(\frac{\mathrm{dR}}{1}+\mathrm{R}\right)
$$

The risk of financial instability on bank value can be measured by the volatility of the portfolio's net worth per market value of assets that have been managed as follows:

$$
\mathrm{d}\left(\frac{\mathrm{PNW}}{\mathrm{A}}\right)=-\mathrm{dG} \cdot \mathrm{dR}+\frac{\mathrm{CG} \cdot}{2} \cdot \frac{\mathrm{dR}^{2}}{(1+\mathrm{R})}
$$

whereby

$$
\mathrm{CG}=\mathrm{CA}-\left(\frac{\mathrm{L}}{\mathrm{A}}\right) \cdot \mathrm{CL}
$$

where

CA : Asset Convexity;

CL : Convexity of Liabilities;

A : Asset Market Value;

L : Market Value of Liabilities;

D : Duration;

$\mathrm{R}$ : Rate of Return.

From the research, it is known that the Net Margin of Islamic banks is influenced by movements in interest rates. In this study we use the SBI (Bank Indonesia Certificate) interest rate as a comparison. The research model also describes the instability of the net margin / income of Bank Syariah Mandiri to changes in interest rates represented by SBI and other independent factors as follows:

$$
\text { Net Margin }=\alpha+\beta 1 \frac{\mathrm{RSA}}{\mathrm{RSL}}+\beta 2 \mathrm{FDR}+\beta 4 \mathrm{CAR}+\beta 5 \mathrm{NPF}+v
$$

The profit rate in Islamic banks, which equates a fair distribution of income as measured by the suitability of Net Margin on the Asset-Liability Management of Islamic banks, can be achieved by separating the management of the Islamic bank's profit repricing profile based on short-term assets (Murabahah, Istina and Salam), long-term investment. medium (Ijara, istina) and long-term partnerships (Mudharabah, Musyarakah). If Asset-Liability management in Islamic banking follows the concept of sharia profit levels. The Net duration of the Islamic Bank's balance sheet will be close to zero or risk neutral so that it is immune to changes in market variables such as interest rates.

The level of profit that creates equal distribution of wealth in the Islamic capital market can be seen from the volatility of Islamic financial assets such as Islamic bonds (sukuk) which are more stable when using concepts that are in accordance with sharia principles. From the ecomonic analysis, we can see that the main factor is the risk premium component added to the price structure of Islamic financial assets such as Islamic bonds which is basically the same addition charged to the loan price structure to compensate for the credibility of the borrower. This risk premium together with the long-term premium structure creates price volatility due to high duration factors. With the concept of rate of profit in accordance with sharia principles, the rate of profit will correspond to profits in the real sector and is always adjusted to changes in prices in the real market (mark to the market) so that the price of the sukuk will be more stable.

\section{Islamic Premi}

The proposed model of the U.S.M. Sohel Azada, Saad Azmatb, Abdelaziz Chazic and Amirul Ahsan [45] is a credit spread structural model as developed by Longstaff and Schwartz [46] to investigate the determinants of Islamic premiums. The structural model used by Collin-Dufresne et al. [47] and Covrig et al. [48]. In particular, Covrig et al. [48] 
used this model to analyze the determinants of the spread between TIBOR (Tokyo Interbank Offer Rate) and LIBOR. After analyzing the long-run equilibrium relationship and the short-term dynamic relationship, we look for the determinant of the IIBR-LIBOR spread or "Islamic premium". The Islamic premium is a reflection of the funding costs and potential benefits of participating IIBR price setters. To corroborate these findings, we model the determinants of the Islamic premium, capturing the effects of interest rates, stock market indices, and news. We suggest that before starting their own benchmark interest rates, Islamic banks should change the way they do business. This change will then be reflected in its benchmark interest rate, which makes it different from conventional banks. The findings of this study indicate the rejection of the decoupling hypothesis of the sharia benchmark interest rate from conventional reference rates such as LIBOR.

\section{CONCLUSION AND RECOMMENDATION}

\section{A. Conclusion}

Based on previous research, the evaluation of the application of pricing for the products of collection and distribution of funds in Islamic banking is determined by each time lag of the variable collection and distribution of funds (credit) in Islamic banking and conventional banking, and vice versa. The existence of a relationship between the interest rate in determining the pricing of fundraising products and the distribution of Islamic banking funds indicates that the practice of Islamic banking in Indonesia has not been completely free from the element of interest rates. Several models have been proposed as benchmarks for pricing in Islamic banking products as an alternative benchmark for interest rates. The alternative proposed model emphasizes the determination of Islamic pricing benchmarks based on real economic activity based on asset productivity and profitability as well as the risk profile of real economic business by considering the risk-taking aspect. Therefore, the benchmark must be based on the level of profit that comes from the real sector.

\section{B. Recommendation}

Islamic banks need to reflect and take steps back that the operational concept of Islamic banks is a bank that operates on the principle of profit and loss sharing without using an interest system. Islamic banks are intermediary institutions that collect public funds from the surplus fund and distributed to the people who suffered a deficit of funds in the form of financial and real economic activity. Therefore, it is better if pricing in Islamic banking products refers to the return from real economic and financial activities as a benchmark at a level that can compete with the interest rates offered by conventional banking.

\section{REFERENCES}

[1] Hamza, H. dan Kachtouli, S (2014), Competitive Conditions and Market Power of Islamic and Conventional Commercial Banks": Journal of Islamic Accounting and Business Research, Vol. 5 No. 1 pp. 29-46. https://doi.org/10.1108/JIABR-05-2012-0030.

[2] Ghauri,S. (2015). "Why Interest-Rate Cannot Benchmark for Islamic Financial Product Pricing?", Benchmarking: An International Journal,
Vol. 22 No. 7, pp. 1417-1428. https://doi.org/10.1108/BIJ-04-20130049 .

[3] Abduh, M. (2017). "Competitive Condition and Market Power of Islamic Banks in Indonesia": International Journal of Islamic and Middle Eastern Finance and Management, Vol. 10 No. 1, pp. 77-91. https://doi.org/10.1108/IMEFM-09-2015-0098.

[4] Sing, Liau-Y. "Islamic Benchmark Financing Rate Not Expected in Near Term": Global Islamic Finance Magazine. Accessed on 2020.

[5] Uj Jaman, Bashir. 2011. Benchmarking in Islamic Finance : Markfield Institud Of Higher Education (Mihe) University of Gloucestershire.

[6] Researchers of Islamic Departement. 2013. "Index of Real Sector Returns as Price Benchmarking for Islamic Banking Products": Tazkia Islamic Finance and Business Review Vol 7.1.

[7] Ghauri,S. (2015). "Why Interest-Rate Cannot Benchmark for Islamic Financial Product Pricing?", Benchmarking: An International Journal, Vol. 22 No. 7, pp. 1417-1428. https://doi.org/10.1108/BIJ-04-20130049 .

[8] Ismail, Abdul Ghafar. 2008. Pricing on the Islamic Banking Products : Working Paper in Islamic Economic and Finance No. 0811.

[9] Saba, Irum dan Nidal Al Sayyeed. 2010. Economic Pricing Mechanism for Islamic Financial Intruments: Ijarah Model. Munich Personal RePec Archive MPRA Paper No. 20685, hhtp://mpra.ub.unimuecher.de/20685/mprapaperno.20685.posted. 16 February 2010 00:29 utc.

[10] Ismail, Abdul Ghafar dan Noraziah Che Arshad. 2010. Pricing on The Islamic Banking Products, Malaysian Management Review, Malaysia.

[11] Ahmed, Sawar Uddin, etc. 2014, "Pricing Lingkage Between Islamic Banking and Conventional Banking: The Case of Bangladesh" International Journal of Finance and Banking Studies, Vol 3, No. 4, 2014.

[12] Anuar, Khairul, etc. 2016. Asian Investor: Apakah Bank Syariah Benar-Benar Bebas Bunga?

https://wwww.asianinvestor.net/article/are-islamicbanks-reallyinterest-rate free/, 5 Mei 2016.

[13] Essia Ries Ahmed, AMd Aminul Islam, Tariq Tawfeeq Yousif Alabdullah, Azlan Bin Amran, 2018. Proposed the Pricing Model as an alternative Benchmark. Benchmarking: An International Journal, Vol 25, Issue: 8, pp. 2892-2912.

[14] Purbayati, Radia. 2019. Evaluasi Praktek Perbankan Syariah di Indonesia: Interest Rate Free? : Ekspansi: Jurnal Ekonomi, Keuangan, Perbankan dan Akuntansi ISSN (Online): 2580-7668 ISSN (Print): 2085-5230 Vol. 11 No. 2 (November 2019), Hal 231-250.

[15] Demilio, R. (1995). The Basics of Benchmarking , Portland, USA:Productivity Press.

[16] Uj Jaman, Bashir. 2011. "Benchmarking in Islamic Finance": Markfield Institud Of Higher Education (Mihe) University of Gloucestershire.

[17] Researchers of Islamic Departement. 2013. Index of Real Sector Returns as Price Benchmarking for Islamic Banking Products: Tazkia Islamic Finance and Business Review Vol 7.1.

[18] Ahmed, et al. 2018. Proposed the Pricing Model as an Alternative Islamic Benchmark: Benchmarking: An International Journal, Vol. 25, Issue 8, pp. 2892-2912.

[19] Omar, et al. 2010. Islamic Pricing Benchmarking: International Shari'ah Research Academy for Islamic Finance No. 17.

[20] Ismail, Abdul Ghafar dan Noraziah Che Arshad. 2010. Pricing on The Islamic Banking Products, Malaysian Management Review, Malaysia.

[21] Saba, Irum dan Nidal Al Sayyeed. 2010. Economic Pricing Mechanism for Islamic Financial Intruments: Ijarah Model. Munich Personal RePec Archive MPRA Paper No. 20685, hhtp://mpra.ub.unimuecher.de/20685/mprapaperno.20685.posted. 16 February 2010 00:29 utc.

[22] Researchers of Islamic Departement. 2013. Index of Real Sector Returns as Price Benchmarking for Islamic Banking Products : Tazkia Islamic Finance and Business Review Vol 7.1.

[23] Pesaran, Hashem \& Smith, Richard \& Shin, Yongcheol. (2001). Bound Testing Approaches to the Analysis of Level Relationship. Journal of Applied Econometrics. 16. 289-326. 10.1002/jae.616.

[24] Ali, Mohsin dan Azmi, Choudarry Wajahat Naeem. 2014. Islamic Finance Benchmark : Journal of Islamin Business and Magement: A Possible Solution Revisited Vol. 4 No. 2.

[25] Supriyanto, Trisilahadi. 2016. "Rate of Profit as a Pricing Benchmark in Islamic Banking to Create Financial Stability": Presented at International Conference on Islamic Economic and Finance. University of Toronto. Canada.

[26] Ahmed, et al. 2018. "Proposed the Pricing Model as an Alternative Islamic Benchmark": Benchmarking: An International Journal, Vol. 25, Issue 8, pp. 2892-2912. 
[27] Haradhan, Mahojan. 2018. "Qualitative Research Methodology in Social Science and Related Subjuects": Journal of Economic Development, Environment and People, Vol. 7, Issue 01, pp. 23-48.

[28] Hart, C. 1998. Doing Literature Review: Releasing the Social Science Research Imagination. London, UK: Sage Publication.

[29] Webster, J dan Watson R. 2002. Analyzing the Past to Prepare for The Future: Writing a Literature Reviews. MIS Quarterly, 26(2), 13-23.

[30] Shaw, J. 1995. A Shema Approach to The Formal Literature Review in Engineering Theses. System, 23(3), 325-335.

[31] Levy dan Ellis. 2006. "A System Approach to conduct an Effective Literature Review in Support of Information System Researc": Informing Science Journal Vol. 9, p. 181-212.

[32] Snyder, Hannah. 2019. "Literature Review as a Reasearch Methodology: An Overview Guidelines": Journal of Business Research Vol 104, pp. 333-339.

[33] Levy dan Ellis. 2006. "A System Approach to conduct an Effective Literature Review in Support of Information System Research": Informing Science Journal Vol. 9, p. 181-212.

[34] Greenhalgh, et al. "A Systematic Literature Review Using the MetaNarrative Methode": Tension and Paradoxex in Electronic Patien Record Research. University College London.

[35] Scherer, F. M. 1971. Industrial Market Structure and Economic Performance. New York: Rand McNally \& Co.

[36] Ross, S. A., 1978. A simple approach to the valuation of risky streams. Journal of Business 51 (July): 453-75.

[37] Gordon, Lawrence A., and Michelle M. Hamer. (1988). Rates of return and cash flow profiles: An extension. Accounting Review, Vol. 63(3): 514-521.

[38] Kassim et al, 2017. "What Drives House Price in Malaysia? In Search of An Alternative Pricing Benchmark for Islamic Home Financing". Journal of the Malaysian Institute of Planners, Volume 15 Issue 4 (2017), pp. 21-34.

[39] Omar et al, 2010. "An Islamic Pricing Benchmark" ISRA Research Paper (No. 17/2010).

[40] Mirakhor, A. (1996), "Cost of Capital and Investment in a Non-Interest Economy", Islāmic Economic Studies, Vol. 4, No. 1.

[41] Iqbal, Z., 2002. "The Benchmark Issue in the Islāmic Financial System", The American Journal of Islāmic Social Sciences, 16: 2, pp. 46-53.

[42] Tobin, J. 1969. "A General Equilibrium Approach to Monetary Theory", Journal of Money Credit and Banking, Vol. 1, February, pp. 15-29.

[43] Fumio, H. 1982. "Tobin's marginal Q and average Q", Econometrica, Vol. 50, pp. 213-224.

[44] Supriyanto, Trisiladi. 2016 "Rate of Profit as a Pricing Benchmark In Islamic Banking" International Conference On Islamic Economic And Finance.

[45] Ahsan et al. 2018. "Can Islamic banks have their own benchmark?" Emerging Markets Review 35 (2018) 120-136. https://doi.org/10.1016/j.ememar.2018.02.002.

[46] Schwartz, Eduardo S \& Longstaff , Francis A. (1995). A Simple Approach to Valuing Risky Fixed and Floating Rate Debt. The Journal $\begin{array}{llll}\text { of Finance (1995), } & 50(3), & 789-819 \text {, }\end{array}$ https://doi.org/10.1142/9789814759595_0011.

[47] Collin et al. 2001. The Determinants of Credit Spread Changes. The Journal of Finance, Vol. 56, No.6. (Dec., 2001), pp. 2177-2207.

[48] Covrig, V., Low, B.S., Melvin, M., 2004. A yen is not a yen: Tibor/libor and the determinants of the japan premium. J. Financ. Quant. Anal. 39 (1), 193-208.

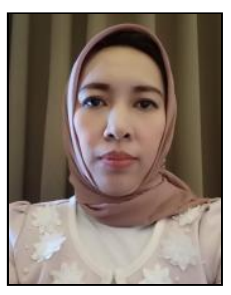

(2002).

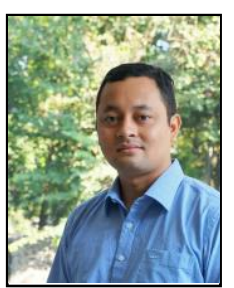

Bank Syariah Indonesia Company for around 10 years.

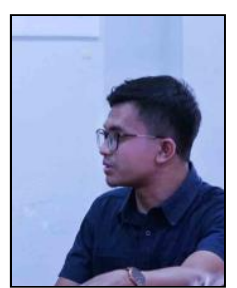

Agil Krisna Rivanda is the full-time staff in finance and accounting. His research interests are in Financial Accounting and Islamic Finance. He graduated with Associate in Finance from Politeknik Negeri Bandung and has also obtained a Bachelor of Accounting from Sekolah Tinggi Ilmu Ekonomi Ekuitas. He has worked in finance and accounting for 5 years. 